Images in...

\title{
An unusual cause of acute liver failure
}

\author{
Pravin Agrawal, ${ }^{1}$ Vidhyachandra Gandhi, ${ }^{1}$ Aabha Nagral, ${ }^{2}$ Sanjay Nagral'
}

${ }^{1}$ Department of Gastrointestinal Surgery, Jaslok Hospital Research Centre, Mumbai, India

${ }^{2}$ Department of Gastroenterology, Jaslok Hospital Research Centre, Mumbai, India

Correspondence to Dr. Aabha Nagral, aabhanagral@gmail.com

\section{DESCRIPTION}

An 80-year-old diabetic and hypertensive lady was admitted with fever associated with chills and pain in the right hypochondrium of 5 days duration. On examination, she was febrile, drowsy and had asterixis. She was icteric and had tenderness with guarding in the right hypochondrium. There was no history of any pre-existing liver disease. Her haemoglobin was $9 \mathrm{~g} / \mathrm{dl}$, total leucocyte count was $11700 / \mathrm{mm}^{3}$, platelets were $1.4 \mathrm{lac} / \mathrm{mm}^{3}$, total bilirubin of $3.3 \mathrm{mg} / \mathrm{dl}$, albumin of $1.9 \mathrm{mg} / \mathrm{dl}$, alkaline phosphatase 227 U/1 (normal 30-150 U/1), SGOT-327 U/1, SGPT-178 U/1 and international normalised ratio (INR) was 2.1. Viral markers for $\mathrm{A}, \mathrm{B}, \mathrm{C}$ and $\mathrm{E}$ were negative. Ultrasonography showed a hypoechoic lesion in the right hepatic lobe. A CECT abdomen revealed a single $8 \times 7 \mathrm{~cm}$ hypodense lesion in segments 5, 6, 7 and 8 with thrombosis of the right portal vein (figure $1 \mathrm{~A}$ ), normal left portal vein (figure $1 \mathrm{~B}$ ) with decreased enhancement of the right lobe and compressed retrohepatic inferior vena cava (IVC) (figure 2). Her serum indirect haemagglutination for Entamoeba histolytica had a titre of 1:2560 (significant titre $>1: 400$ ) suggestive of an amoebic liver abscess (ALA) and was started on metronidazole. Anchovy sauce-like pus was aspirated $(600 \mathrm{ml})$ from the abscess which did not grow any organism. She improved in terms of consciousness, inotrope requirements and INR (1.4) and bilirubin (1.8 mg/dl). She had started taking oral diet gradually, but had a large vomit following which she developed aspiration pneumonia, went into acute respiratory distress and succumbed.

Vascular complications with ALA have been described in the form of involvement of hepatic veins and IVC causing Budd-Chiari syndrome either by compression or thrombosis. ${ }^{1}{ }^{2}$ Jaundice is uncommon and could be due to obstruction of biliary radicles, ${ }^{3}$ or as in this case was secondary to the liver failure. ALA presenting as liver failure is rare and is not because of hepatocyte dysfunction, but due to compromised blood flow either from portal vein, hepatic vein or IVC compression, as was seen in our patient. In literature, an autopsy series of 79 patients with ALA described portal vein thrombosis in $27 \%$ of patients. ${ }^{4}$ However, literature is scarce in the form of clinical case reports or imaging studies, documenting portal vein thrombosis in an ALA as a cause of liver failure.
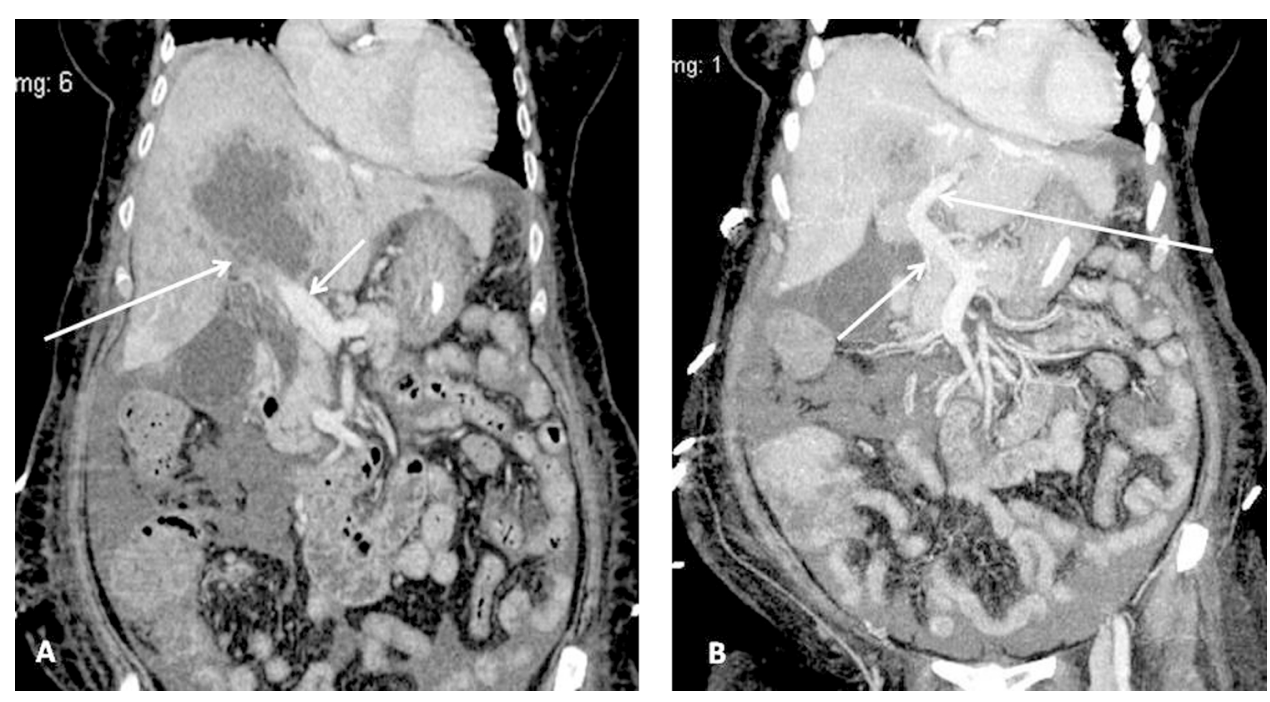

Figure 1 (A) Coronal section of CECT abdomen showing abscess in the segment 5, 6,7 and 8 of right lobe of the liver with thrombosis of the right portal vein (long arrow) with normal main portal vein (short arrow). (B) Coronal section of CECT of abdomen showing abscess cavity normal main portal vein (short arrow) and left portal vein (long arrow). 


\section{BMJ Case Reports}

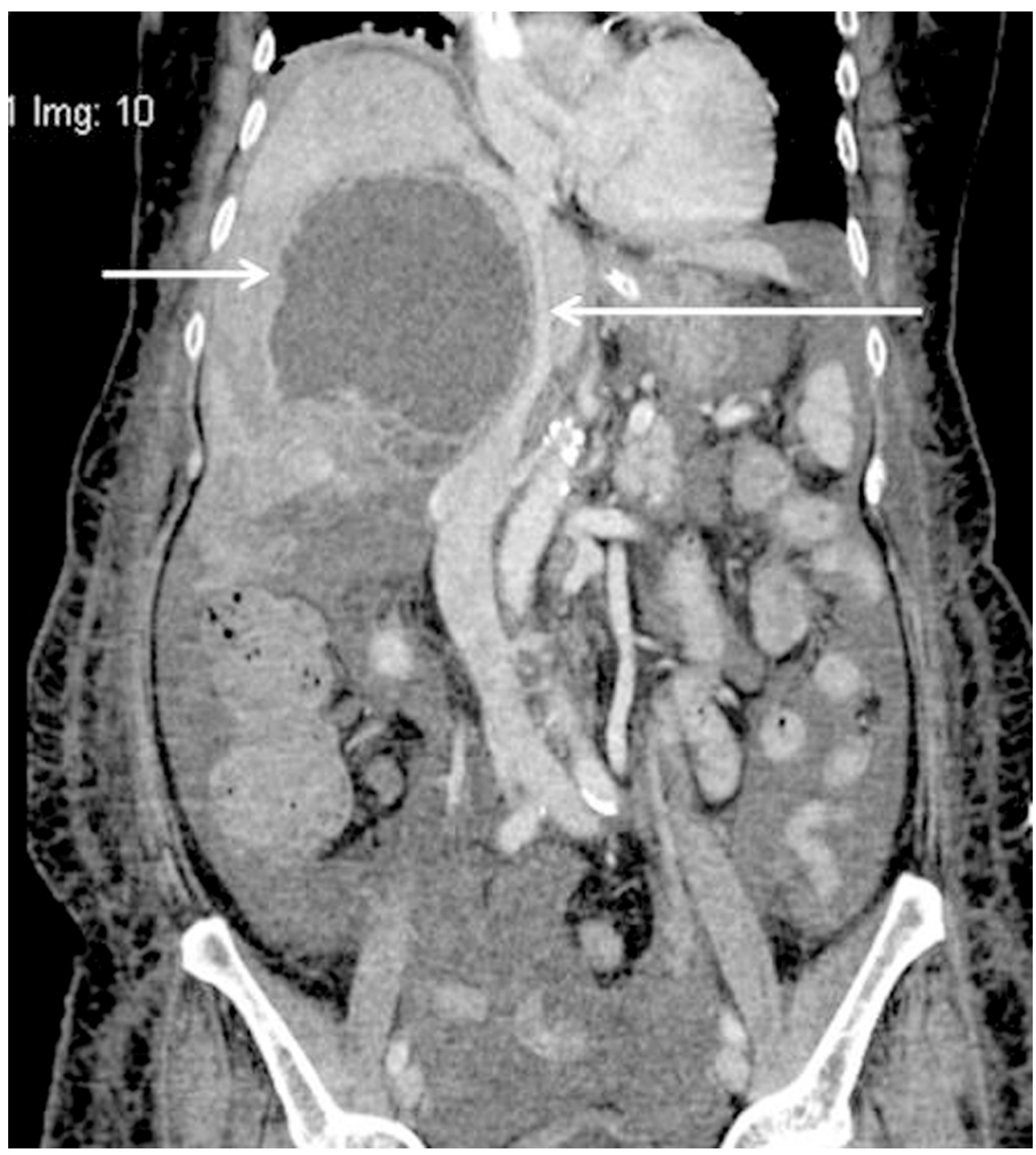

Figure 2 Coronal section of CECT of abdomen showing abscess cavity (short arrow) mainly in the right lobe of the liver with compressed IVC (long arrow).

\section{Learning points}

- In a patient of ALA presenting with liver failure, vascular involvement should be suspected and CECT scan should be done, as it is the most sensitive investigation.

- Patients with ALA and liver failure need to be treated on an emergency basis either by ultrasound-guided aspiration or open laparotomy and drainage depending on the clinical condition and the site of the abscess.

\section{REFERENCES}

1. Krishnan K, Badarinath S, Bhusnurmath SR. Vascular complications of hepatic amoebiasis - a retrospective study. Indian J Pathol Microbiol 1986;29:293-6.

2. Kushaljit SS, Vijayanadh 0, Vinay S, et al. Hepatic and inferior vena cava thrombosis: vascular complication of amebic liver abscess. J Emerg Med 2007; $34: 155-7$.

3. Singh V, Bhalla A, Sharma N, et al. Pathophysiology of jaundice in amoebic liver abscess. Am J Trop Med Hyg 2008;78:556-9.

4. Aikat BK, Bhusnurmath SR, Pal AK, et al. The pathology and pathogenesis of fatal hepatic amoebiasis - a study based on 79 autopsy cases. Trans $R$ Soc Trop Med Hyg 1979;73:188-92. 


\section{BMJ Case Reports}

This pdf has been created automatically from the final edited text and images.

Copyright 2010 BMJ Publishing Group. All rights reserved. For permission to reuse any of this content visit

http://group.bmj.com/group/rights-licensing/permissions.

BMJ Case Report Fellows may re-use this article for personal use and teaching without any further permission.

Please cite this article as follows (you will need to access the article online to obtain the date of publication).

Agrawal P, Gandhi V, Nagral A, Nagral S. An unusual cause of acute liver failure. BMJ Case Reports 2010;10.1136/bcr.03.2010.2837, date of publication

Become a Fellow of BMJ Case Reports today and you can:

- Submit as many cases as you like

Enjoy fast sympathetic peer review and rapid publication of accepted articles

Access all the published articles

- Re-use any of the published material for personal use and teaching without further permission

For information on Institutional Fellowships contact consortiasales@bmjgroup.com

Visit casereports.bmj.com for more articles like this and to become a Fellow 